\title{
CONCEPTION RATE DAN SERVICE PER CONCEPTION PADA SAPI PERAH AKSEPTOR INSEMINASI BUATAN DI KUD ARGOPURO KECAMATAN KRUCIL KABUPATEN PROBOLINGGO
}

\section{CONCEPTION RATE AND SERVICE PER CONCEPTION OF DAIRY CATTLE ACCEPTOR ARTIFICIAL INSEMINATION IN KUD ARGOPURO KRUCIL DISTRICT PROBOLINGGO REGION}

\author{
Nadia Yohana ${ }^{1)}$, Abdul Samik ${ }^{2)}$, E. Bimo Aksono ${ }^{3)}$, Trilas Sardjito ${ }^{4)}$, Herry Agoes \\ Hermadi $^{\text {) }}$, Tjuk Imam Restiadi ${ }^{6}$ \\ ${ }^{1)}$ Student, ${ }^{2,4,5,6)}$ Departement of Reproduction Veterinary, ${ }^{3)}$ Departement of Basic Medical \\ Veterinary \\ Faculty of Veterinary Medicine Airlangga University
}

\begin{abstract}
Reproduction is one of essential factor directly affecting profitability in a dairy production system. Some of the reproductive factors that influenced to the developing of dairy cattle of small holder's farmer are Conception Rate (CR) Service per Conception (S/C). The study was conducted to know the CR and S/C of Friesian Holstein in KUD Argopuro, Probolinggo. The data is taken primary and secondary data. Primary data retrieval is done by direct observation, which includes several variables, where the variables include : the identity of the breeder, cages, and feeding and drinking. As for the secondary data obtained by recording the card Artificial Insemination (AI) owned by Inseminator in KUD Argopuro. The data which by collected from this sample are CR and S/C. This research was a case study. The materials used cattle as the acceptors were $10 \%$ from 728 lactation cattle. Data from the results of this research on CR $(30 \%)$ and S/C $(2,49)$. The conclusion of this research for CR the result were lower than normal and $\mathrm{S} / \mathrm{C}$ the result were higher than normal.
\end{abstract}

Key words : Reproductive efficiency, artificial insemination, Friesian Holstein

\section{Pendahuluan}

Sapi adalah hewan yang dipelihara untuk dimanfaatkan didapatkan susu dan daging untuk dimakan manusia. Sapi perah adalah jenis sapi yang dipelihara dengan tujuan untuk menghasilkan air susu (Blakely dan Bade, 1998). Sapi perah yang ada di Indonesia biasanya berasal dari New Zealand dan Australia. Sapi perah adalah sapi yang diternakkan terutama sebagai penghasil susu. Tuntutan kebutuhan pangan masyarakat dunia yang terus meningkat setiap tahun menjadi penyebab utama digunakannya teknik Inseminasi Buatan pada hewan ternak guna meningkatkan efisiensi pada produktivitas dan reproduktivitas hewan ternak (Hardijanto dkk, 2010). Inseminasi Buatan (IB) telah dikenal di Indonesia sebagai salah satu teknologi reproduksi yang efektif dan telah umum dilaksanakan di kalangan peternak. Di Indonesia pelaksanaan IB lebih sering dilakukan pada ter- nak besar, khususnya sapi. Baik itu sapi potong maupun sapi perah.

Proses peletakkan atau deposisi semen di dalam saluran kelamin betina pada dasarnya menggunakan alat buatan. Semen yang dipakai dapat berupa semen beku ataupun semen segar. Penggunaan IB vertujuan sebagai upaya peningkatan produktivitas dan reproduktivitas pada ternak. Hal ini tergantung pada arah tujuan dari peternakan tersebut yaitu penyediaan daging atau peningkatan produktivitas susu. Efisiensi reproduksi inseminasi dapat diketahui dengan beberapa penilaian, yaitu berdasarkan Conception Rate (CR), berupa pemeriksaan kebuntingan yang didasarkan pada jumlah akseptor yang bunting pada IB ke I dibagi jumlah semua akseptor kali 100\% (Hafez and Jaenudeen, 2000), serta dapat juga diketahui dengan mengukur Service per Conception (S/C) merupakan jumlah pelayanan inseminasi untuk meng- 
hasilkan kebuntingan. Semakin kecil nilai S/C ini menandakan semakin efisien IB yang dilakukan. Nilai S/C yang normal berkisar antara 1,6 sampai 2,0 (Toelihere, 2000). Semua faktor ini saling berkaitan dan mempengaruhi keberhasilan IB. Penilaian efisiensi reproduksi IB penting dilakukan dengan tujuan untuk melihat seberapa efektif dan efisien pelaksanaan program IB di suatu daerah. Daerah yang digunakan untuk penelitian ini di KUD (Koperasi Unit Desa) Argopuro, Kecamatan Krucil, Kabupaten Probolinggo - Provinsi Jawa Timur.

\section{Materi dan Metode}

Materi yang digunakan dalam penelitian ini adalah catatan reproduksi sapi perah Friesian Holstein betina produktif di KUD (Koperasi Unit Desa) Argopuro kecamatan Krucil, Kabupaten Probolinggo, Provinsi Jawa Timur selama periode 2014-2015. Data sapi perah yang di Inseminasi Buatan selama tahun 2014. Data diperoleh dari dokumen-dokumen yang berasal dari 10\% dari 723 ekor sapi Friesian Holstein betina hasil IB (Inseminasi Buatan) yaitu sekitar 70 ekor terdapat dari peternak yang berada di sekitar KUD (Koperasi Unit Desa) Argopuro, Kecamatan Krucil, Kabupaten Probolinggo - Provinsi Jawa Timur. Peralatan yang disediakan adalah lembaran yang berisi tentang pencatatan sistem reproduksi.
Metode yang digunakan dalam penelitian ini adalah metode survei.

\begin{abstract}
Analisis Data
Data yang diperoleh dilakukan dengan mengumpulkan data primer dan data sekunder dari catatan reproduksi induk sapi perah Friesian Holstein betina produktif di KUD (Koperasi Unit Desa) Argopuro Kecamatan Krucil, Kabupaten Probolinggo, Provinsi Jawa Timur dan data dari peternak. Data yang sudah terkumpul disajikan dalam bentuk tabel dan hasilnya merupakan data dalam bentuk deskriptif. Data yang terkumpul untuk mendapatkan efisiensi reproduksi dari sapi perah meliputi : Conception Rate (CR) dan Service per Conception (S/C).
\end{abstract}

\section{Hasil dan Pembahasan}

Hasil penelitian berdasarkan data sekunder dari inseminator dan juga hasil wawancara dengan peternak yang kemudian diolah didapatkan CR sebesar 30\% dan didapatkan S/C sebesar 2,49 kali. Penelitian ini dilakukan dengan menggunakan data sekunder dari inseminator serta survei berupa wawancara dengan beberapa peternak dengan jumlah 70 ekor sapi perah akseptor IB kemudian diperoleh hasil seperti yang terlihat dari tabel

Tabel 1. Hasil Penelitian CR dan S/C Sapi Perah Friesian Holstein KUD Argopuro Kecamatan Krucil Kabupaten Probolinggo

\begin{tabular}{|ccccc|}
\hline NO & Efisiensi Reproduksi & $\begin{array}{c}\text { Hasil } \\
\text { Perhitungan }\end{array}$ & $\begin{array}{c}\text { Nilai } \\
\text { Normal }\end{array}$ & Keterangan \\
& & $30 \%$ & $>60 \%$ & Kurang Baik \\
1 & Conception Rate $(\mathrm{CR})$ & $2,49 \mathrm{kali}$ & $1,6-2,0$ kali & Kurang Baik \\
2 & Service per Conception $(\mathrm{S} / \mathrm{C})$ & &
\end{tabular}

Tabel 2. Hasil Pelayanan Inseminasi Buatan pada Sapi Perah Friesian Holstein sampai terjadi kebuntingan

\begin{tabular}{ccc}
\hline NO & Frekuensi IB & Ekor \\
\hline 1 & Bunting pada IB 1 & 21 \\
2 & Bunting pada IB 2 & 22 \\
3 & Bunting pada IB 3 & 10 \\
4 & Bunting pada IB 4 & 10 \\
5 & Bunting pada IB 5 & 3 \\
6 & Bunting pada IB >5 & 4 \\
\hline & Jumlah & $\mathbf{7 0}$ \\
\hline
\end{tabular}




\section{Conception Rate (CR) pada Sapi Perah Friesian Holstein}

Salah satu komponen untuk menilai baik tidaknya pemberian Inseminasi Buatan (IB) yaitu Conception Rate (CR) atau Angka Konsepsi. CR merupakan angka presentase ternak yang bunting hasil inseminasi pertama pada seluruh ternak yang diinseminasi. Hasil penelitian ini membuktikan nilai CR sapi perah sebesar $30 \%$ seperti tampak pada (Lampiran 2). Nilai normal CR menurut Hariadi, dkk (2011) adalah 6575\% sehingga nilai CR penelitian ini masih di bawah nilai normal. Nilai CR pada penelitian ini lebih rendah dari pada nilai yang diperoleh Kurnia (2016) yang mendapatkan nilai CR adalah $61,71 \%$. Kondisi ini mungkin terjadi karena beberapa faktor yang dapat mempengaruhi nilai $\mathrm{CR}$ sapi perah di Krucil Probolinggo. Nilai CR ditentukan oleh kesuburan pejantan, kesuburan betina, dan teknik inseminasi (Hafez, 2000). Rendahnya CR di KUD Argopuro Krucil dapat disebabkan pendidikan peternak yang sebagian besar tingkat SD yaitu $66,67 \%$ serta tertinggi tingkat SMA sebesar $4,17 \%$. Peternak segera melapor ke inseminator di tiap wilayah untuk segera dilakukan IB. Pemeliharaan sapi perah di KUD Argopuro pada umumnya menjadi satu dengan rumah peternak (mixed farming system).

Nilai Conception Rate sangat berkaitan erat dengan keadaan akseptor ternak. Faktor ini tidak hanya dilihat dari performan akseptor namun ada beberapa faktor yang patut dipertimbangkan seperti tingkat stress ternak, status reproduksi dan mutu genetik. Pengetahuan yang kurang dari peternak tentang nutrisi pakan, serta lingkungan juga terkadang dapat menjadi salah satu penyebabnya. Nutrisi pakan yang rendah dapat menyebabkan kawin berulang serta kematian embrio dini. Sapi perah laktasi membutuhkan protein tinggi sekitar $17-18 \%$ untuk menunjang produksi susu, sehingga perlu adanya kandungan nutrisi yang baik untuk memenuhi kebutuhan pokok ternak serta untuk produksi (Hariadi dkk., 2011). Pemberian pakan di KUD Argopuro umumnya rumput gajah, serta untuk campran dengan lamtoro, cliriside, rumput lapangan serta rumput odod. Pemberian konsentrat dengan agrovit dan silase yang dibuat di KUD Argopuro. Menurut penjelasan sebelumnya nutrisi pakan yang dibutuhkan untuk sapi perah laktasi membutuhkan protein lebih tinggi, untuk menunjang produksi susu sehingga perlu pakan dengan kandungan nutrisi yang baik sehingga pemberian pakan dengan kandungan nutrisi yang baik dapat meningkatkan gejala birahi yang jelas (Hariadi dkk., 2011).

Variasi lingkungan mempengaruhi kebuntingan sapi pada Inseminasi Pertama serta nutrisi pakan juga berpengaruh pada kesehatan reproduksi sapi bunting dan beranak yang merupakan faktor keberhasilannya Inseminasi Buatan (IB). Sapi perah yang kekurangan nutrisi pakan saat sebelum proses melahirkan berdampak pada tertundanya siklus estrus pada sapi tersebut (Hariadi dkk., 2011). Produksi susu yang tinggi juga dapat menyebabkan CR rendah.

Kondisi ternak yang sehat, deteksi estrus, dan pengelolaan reproduksi yang baik dapat mempengaruhi pada fertilitas dan Conception Rate (CR) pada sapi perah (Nebel, 2002). Faktor penting dalam keberhasilan Conception Rate (CR) adalah ketepatan deteksi estrus dan saat inseminasi berlangsung serta kualitas semen dan kemahiran inseminator (Hardijanto dkk., 2011).

\section{Service per Conception (S/C) pada Sapi Perah Friesien Holstein}

Service per Conception atau jumlah inseminasi per kebuntingan yang biasa disingkat dengan S/C (Service per Conception) merupakan jumlah pelayanan inseminasi untuk menghasilkan kebuntingan. Idealnya nilai S/C (Service per Conception) adalah satu, dan kisaran normal adalah 1,6 sampai 2,0. Semakin tinggi tingkat kesuburan ternak maka nilai S/C (Service per Conception) yang dihasilkan akan semakin rendah. Sebaliknya semakin tinggi nilai S/C (Service per Conception) dapat diduga bahwa tingkat kesuburan ternak tersebut rendah (Hafez, 2000). Berdasarkan data primer dari peternak dan data sekunder dari inseminator yang kemudian diolah (Lampiran 1) hasil S/C di KUD Argopuro sebesar 2,49 kali. Hasil S/C pada penelitian ini lebih tinggi dari nilai yang diperoleh Muhhamad (2015) yaitu 2,1 kali.

Hadi dan Ilham (2004) mengungkapkan penyebab tingginya angka S/C (Service per Conception) umumnya dikarenakan : (1) peternak terlambat mendeteksi birahi 
atau terlambat melaporkan birahi sapinya kepada inseminator sehingga pelaksanaan Inseminasi Buatan (IB) mundur dari waktu birahi; (2) adanya kelainan pada alat reproduksi induk sapi (3) inseminator kurang terampil; (4) fasilitas pelayanan inseminasi yang terbatas, dan (5) kurang lancarnya transportasi. Semen beku yang baik harus memenuhi standarisasi Nasional Indonesia Semen Beku menyatakan bahwa semen be$\mathrm{ku}$ yang baik berasal dari pejantan yang unggul, sehat, bebas dari penyakit hewan menular serta diencerkan sesuai prosedur sehingga menjadi semen beku yang disimpan didalam rendaman nitrogen cair dengan suhu $-196^{\circ} \mathrm{C}$ dalam kontainer kriogenik, proses thawing menggunakan wadah berisi air diperlukan untuk pencairan semen atau mengaktifkan kembali semen yang dibekukan (Hardijanto dkk., 2011).

Keberhasilan S/C (Service per Conception) dapat dipengaruhi oleh faktorfaktor sebagai berikut : kualitas semen yang digunakan, deteksi birahi yang tepat, tingkat kemampuan inseminator, dan bobot hidup ternak (Hardijanto dkk., 2011). Nutrisi pakan yang dibutuhkan untuk sapi perah laktasi membutuhkan protein lebih tinggi, untuk menunjang produksi susu sehingga perlu pakan dengan kandungan nutrisi yang baik sehingga pemberian pakan dengan kandungan nutrisi yang baik dapat meningkatkan gejala birahi yang jelas (Hariadi dkk., 2011).

Kegagalan kebuntingan yang terdapat dari data primer yang diperoleh dapat dipengaruhi oleh faktor-faktor sebagai berikut : (1) deteksi birahi peternak yang sebagian hanya mengerti apabila sapi tersebut birahi sehingga terjadinya kawin berulang serta kematian embrio dini; (2) waktu IB yang ditentukan dan teknik IB yang dilakukan oleh inseminator. Waktu IB yang baik sekitar 8-12 jam setelah birahi terlihat; (3) Kualitas semen yang berkurang pada saat di lapangan pada saat thawing yang kurang sesuai prosedur direndam dalam ember berisi air sekitar 30 detik pengambilan straw menggunakan pinset; (4) Penyakit yang menyerang organ reproduksi sapi bisa dicegah dengan kondisi kandang yang bersih, kering serta konsumsi pakan yang memadai.

\section{Kesimpulan}

Hasil yang didapat dari penelitian tentang perhitungan Conception Rate (CR) rendah dan Service per Conception (S/C) tinggi di KUD Argopuro Kecamatan Krucil Kabupaten Probolinggo. Nilai Conception Rate (CR) yang didapat sebesar $30 \%$ dan Service per Conception (S/C) sebesar 2,49 kali.

\section{Daftar Pustaka}

Blakely, J. dan D. H. Bade. 1998. Ilmu Peternakan. Edisi Keempat. Terjemahan : B. Srigandono. Gadjah Mada University Press, Yogyakarta. 94-97

Hafez, E.S.E. 2000. Reproduction in Farm Animals. 7th Ed.Lippincott Wiliams \& Wilkins. Maryland. USA. 165.

Hardijanto., S. Susilowati, T. Hernawati, T. Sardjito dan T. W. Suprayogi. 2010. Buku Ajar Inseminasi Buatan. Airlangga University Press. Surabaya. $55-68$

Hariadi, M., S. Hardjopranjoto.,Wurlina., H.A. Hermadi., B. Utomo., Rimayanti., I.N. Trianadan H. Ratnani. 2011. Ilmu Kemajiran pada Ternak. Cetakan 1. Airlangga University Press. Surabaya. 94-145.

Kurnia, W. 2016. Service per Conception (S/C) dan Conception Rate (CR) Sapi Perah Peranakan Friesian Holstein Akseptor Inseminasi Bua-tan (IB) di KUD Karangploso Ka-bupaten Malang. (Skripsi). Fakultas Kedokteran Hewan. Universitas Airlangga. Surabaya.

Muhammad, F. 2015. Efisiensi Reproduksi Sapi Perah Akseptor IB di Wilayah Kerja KPSP Setia Kawan Nongkojajar Pasuruan. (Skripsi). Fakultas Kedokte-ran Hewan. Universitas Airlangga. Surabaya.

Nebel, R.L. 2002 What should you AI Conception Rate be. Extension Dairy Scientist Reproductive Management. Virginia State University. 1-13

Situmorang dan Gede, 2003. Peningkatan Efisiensi Reproduksi melalui Perkawinan Alam dan Pemanfaatan Inseminasi Buatan untuk Mendukung Program Pemuliaan. Lokakarya Sistem Integrasi Kelapa Sawit-Sapi Balai Penelitian Ternak. 103-109 
Sutarto, T.N dan Sutarto. 2005. Beternak Sapi Perah. Musi Perkasa Utama. Jakarta. 1

Toelihere, M.R. 2000. Animal reproduction in Indonesia State of Art. Makalah $4^{\text {th }}$ International Meeting on Biotecnology in Animal Reproduction. Bogor. 75-89
Zainudin.M, M.N. Ihsan, dan Suyadi. 2014. Efisiensi Reproduksi Sapi Perah PFH pada Berbagai Umur di CV. Milkindo Berka Abadi Desa Tegalsari Kecamatan Kepanjen Kabupaten Malang. Jurnal Ilmu-Ilmu Peternakan 24(3): 32-37 